\title{
Comparison of the miR-23b and miR-203 Expressions in Endometrial Cancer
}

\author{
Kyung Eun Lee Le $^{1,2}$ \\ ${ }^{1}$ Department of Clinical Laboratory Science, College of Health Sciences, Catholic University of Pusan, Busan, Korea \\ ${ }^{2}$ Brain Busan 21 Project for Catholic University of Pusan, Busan, Korea
}

\section{자궁내막암종에서 miR-23b와 miR-203 발현 비교}

\author{
이경은 ${ }^{1,2}$ \\ ${ }^{1}$ 부산가톨릭대학교 보건과학대학 임상병리학과, ${ }^{2}$ Brain Busan 21 사업단
}

\begin{abstract}
MicroRNAs (miRNAs/miRs) are a group of small noncoding RNAs that modulate gene expression. Many studies, demonstrating altered expressions of specific miRNAs in diverse types of human neoplasia, suggested that they may play a key role in tumorigenesis. Recently, miRNA genes were found to be abnormally expressed in several types of cancer, including endometrial cancer. However, miR-23b and miR-203 expression in endometrial cancer has yet to be studied in Korea. As such, the purpose of this study was to analyze miR-23b and miR-203 expressions in endometrial cancer and to evaluate the relationship between miR-23b and miR-203 expressions. A retrospective study was carried out on the formalin-fixed, paraffin-embedded tissues of 42 endometrial cancer tissues using quantitative real-time PCR. In endometrial cancer tissues, miR-23b expression levels $(2.70 \pm 4.45)$ were higher than miR-203 expression levels $(-2.34 \pm 4.08)$. Endometrial cancer tissues showed an overexpression of miR-23b in $30(71.4 \%)$ of the 42 endometrial cancer cases, whereas miR-203 was underexpressed in $29(69.0 \%)$ of the 42 cases. There was a significant association between miR-23b and miR-203 expressions in endometrial cancer tissues ( $p=0.0005$ ). These findings suggest that miR-23b and miR-203 expressions may be involved in endometrial carcinogenesis. More studies are needed to further define the relationship between miR-23b and miR-203 expressions and tissue-specific protein expression.
\end{abstract}

Key words: miR-23b, miR-203, Endometrial cancer

This is an Open Access article distributed under the terms of the Creative Commons Attribution Non-Commercial License (http://creativecommons.org/licenses/by-nc/4.0) which permits unrestricted non-commercial use, distribution, and reproduction in any medium, provided the original work is properly cited.

Copyright @ 2017 The Korean Society for Clinical Laboratory Science. All rights reserved.
Corresponding author: Kyung Eun Lee Department of Clinical Laboratory Science, College of Health Sciences, Catholic University of Pusan, 57 Oryundae-ro, Geumjeong-gu, Busan 46252, Korea

Tel: 82-51-510-0562

Fax: 82-51-510-0568

E-mail: kelee@cup.ac.kr

Received: October 19, 2017

Revised: October 25, 2017

Accepted: October 30, 2017

\section{INTRODUCTION}

Endometrial cancer incidence has shown a marked increase in Korea recently. Determining the causes of endometrial cancer has already yielded much research attention. However, the molecular events that lead from estrogen stimulation to tumor development remain unclear. Epigenetic changes in gene expression caused by chromatin without DNA mutation, such as microRNA (miRNA/miR) regulation, are now receiving attention as possible causes of cancer [1]. miRNAs are a class of small noncoding RNAs that regulate gene expression at the post-transcriptional level [1]. They bind to 3'-untranslated (3'-UTR) regions of target messenger RNAs (mRNAs), blocking translation and mRNA degradation [2]. They play an important role in essential cellular processes, including 
cell differentiation, growth, and death [2,3]. Several studies have demonstrated the altered expression of specific miRNAs in different types of human neoplasia, suggesting that they play a key role in tumorigenesis [4,5]. However, the biological mechanisms of miRNAs are not fully understood, and studies on the role of miRNAs in the development of endometrial cancer are scarce in Korea.

The expression of miRNAs can serve as a biomarker for cancer diagnosis, as changes in miRNA expression are involved in the initiation, progression, and metastasis of human cancer [2,3]. Several miRNAs have been shown to be dysregulated in endometrial cancer, including miR-205, miR-429, miR-210, miR-204, miR-23b and miR-203 [6-8]. However, the possible involvement of miRNA expression in endometrial cancer remains to be established. Many studies have identified either upregulated or downregulated miRNAs in cancer tissues [9]. Among these, findings on miR-23b and miR-203 expression in cancer tissues have been inconsistent; miR-23b has been reported to be upregulated in gastric cancer and to act as an oncogene [10]. However, other studies have reported that miR-23b is significantly downregulated in bladder cancer tissues and acts as a tumor suppressor gene [11]. miR-203 expression has been found to be upregulated in psoriasis, breast cancer, and ovarian cancer, whereas its downregulation has been reported in brain tumors, esophageal cancer, lymphomas, and leukemia [12]. Thus, the etiology of miR-23b and miR-203 expression in endometrial cancer has not yet been elucidated in Korea. Thus, the present study was conducted to analyze miR-23b and miR-203 expression in endometrial cancer and to evaluate the relationship between miR-23b and miR-203 expression.

\section{MATERIALS AND METHODS}

\section{Tissue samples}

A retrospective study was carried out on 42 formalin-fixed, paraffin-embedded (FFPE) tissues from endometrial cancer patients admitted to a local hospital in Busan from 2010 to 2013. The ages of the 42 patients ranged from 32 to 69 years (median age: 49 years). All cancer samples were obtained by endometrial curettage, and histopathologically confirmed; no patients had undergone any preoperative chemotherapy or radiotherapy. The HE stained tissues were reviewed in each case to confirm the original diagnosis, which was based on the International Federation of Gynecology and Obstetrics (FIGO) classification. Histologic diagnoses were reviewed by independent pathologists.

\section{Total RNA extraction}

Four $10 \mu \mathrm{m}$ thick sections of FFPE endometrial cancer tissues from each paraffin block were used for total RNA extraction. The paraffin was removed from the samples by placing them in $1 \mathrm{~mL}$ of $100 \%$ xylene, heating for $3 \mathrm{~min}$ at $56^{\circ} \mathrm{C}$ to melt the paraffin, and then centrifuging for $2 \mathrm{~min}$ at room temperature at 20,000 $\times \mathrm{g}$ to pellet the tissue. After centrifugation, the xylene was removed and $1 \mathrm{~mL}$ of absolute ethanol (EtOH) was added. After mixing, the sample was centrifuged again at 20,000 $\times$ g for 2 min at room temperature and the $\mathrm{EtOH}$ was discarded without disturbing the pellet. The ethanol washing process was repeated twice, removing as much residual $\mathrm{EtOH}$ as possible without disturbing the pellet. Finally, the pellet was air dried for approximately $30 \mathrm{~min}$.

The RecoverAll Total Nucleic Acid Isolation Optimized for FFPE Samples kit (Ambion Inc., Austin, Texas, USA) was used according to the manufacturer's protocol. The proteins were degraded with 100 200 $\mu \mathrm{L}$ digestion buffer and $4 \mu \mathrm{L}$ protease, followed by incubation for $15 \mathrm{~min}$ at $50^{\circ} \mathrm{C}$, and for $15 \mathrm{~min}$ at $80^{\circ} \mathrm{C}$. The RNA was then isolated by adding $790 \mu \mathrm{L}$ of buffer including absolute ethanol, followed by passage through a purification column. The column was then washed twice with a buffer from the kit, and DNase treatment was performed, followed by two additional washings. Finally, RNA was eluted into $60 \mu \mathrm{L}$ of elution buffer from the kit at room temperature according to the manufacturer's instructions. All steps in the preparation and handling of total RNA were conducted in a laminar flow hood under RNase-free conditions. The isolated total RNA was stored at $-70^{\circ} \mathrm{C}$ until use. 


\section{MicroRNA TaqMan reverse transcriptase reaction}

Complementary DNA (cDNA) was synthesized using microRNA TaqMan Reverse Transcription Kit and triplicate TaqMan MicroRNA Assays (Applied Biosystems, Foster City, CA, USA) according to the manufacturer's recommendations. A $5 \mu \mathrm{L}$ sample of total RNA was used for RT, using stem-loop RT primers for each miR. For each reaction, $1.5 \mu \mathrm{L}$ of RT buffer, $0.15 \mu \mathrm{L}$ of $100 \mathrm{mM}$ dNTP, 1 $\mu \mathrm{L}$ of Reverse-Transcriptase, $0.186 \mu \mathrm{L}$ of RNase inhibitor and $3 \mu \mathrm{L}$ of RT primer were mixed. Purified water was added to reach a final volume of $15 \mu \mathrm{L}$. The cDNA synthesis reaction by RT-PCR was performed at $16^{\circ} \mathrm{C}$ for $30 \mathrm{~min}, 42^{\circ} \mathrm{C}$ for $30 \mathrm{~min}$, and $85^{\circ} \mathrm{C}$ for $5 \mathrm{~min}$.

\section{Quantitative real-time PCR (qRT-PCR) assay}

The qRT-PCR of cDNA obtained from miR was performed with TaqMan Universal PCR Master Mix and TaqMan Human MicroRNA Assays (Applied Biosystems, Foster City, CA, USA) using a real-time PCR for thermal cycling and fluorescence detection. Real-time PCR amplification of miRNA was performed in a reaction mix containing $10 \mu \mathrm{L}$ of master mix, $1.33 \mu \mathrm{L}$ of template cDNA, $1 \mu \mathrm{L}$ of $20 \times$ primers, and $7.67 \mu \mathrm{L}$ of distilled water (DW) to give a final volume of $20 \mu \mathrm{L}$ for each sample. The reaction mixture was incubated in a strip at 95 for $10 \mathrm{~min}$, and 40

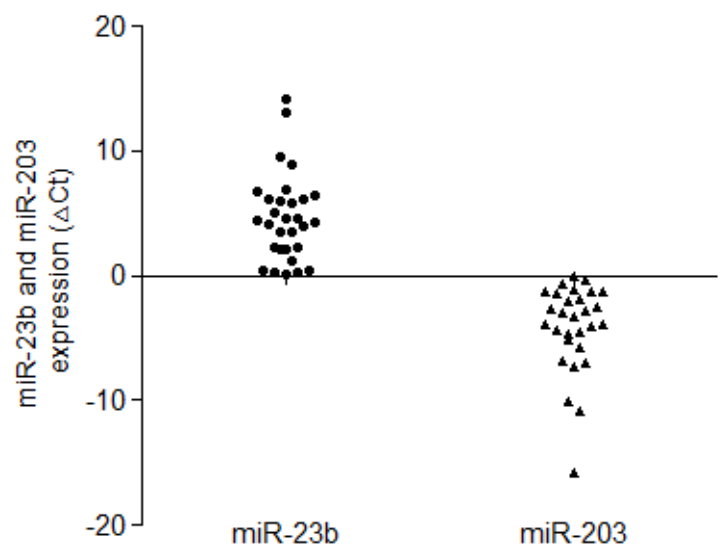

Figure 1. Comparison of miR-23b and miR-203 expression in endometrial cancer tissues. The average standard deviation of each cycle threshold value between the duplicate data for miR-23b and miR-203 indicated that the miR-23b expression level was higher in endometrial cancer tissues $(2.70 \pm 4.45)$ than the miR-203 expression level $(-2.34 \pm 4.08)$. cycles of $95^{\circ} \mathrm{C}$ for $15 \mathrm{sec}$ and $60^{\circ} \mathrm{C}$ for $1 \mathrm{~min}$ for Real-Time PCR. The U6 small nuclear 2 (RNU6b) was used to normalize the input of total small RNA. Absolute quantification for each miR as well as RNU6b was performed using a generated standard curve and expression of each miR was presented as the ratio between miR and RNU6b expression. The relative expression level of each miR-23b and miR-203 were measured using the $\Delta \mathrm{Ct}$ method and the following formula: $\Delta \mathrm{Ct}=\mathrm{Ct}$ (miR-23b or miR-203) $-\mathrm{Ct}$ (RNU6b), where Ct represents the threshold cycle number.

\section{Statistical analysis}

Statistical analysis was performed using SPSS for Windows Standard version 18.0 (SPSS Inc., Chicago, IL, USA). The Fisher exact test was performed to assess the relationship between the expression patterns of miR-23b and miR-203. A $p$-value less than 0.05 was considered statistically significant.

\section{RESULTS}

We determined the levels of miR-23b and miR-203 expression in endometrial cancer tissues ( $\mathrm{N}=42)$ using quantitative real-time polymerase chain reaction (qRT-PCR). The average standard deviation of each cycle threshold value between the duplicate data for miR-23b and miR-203 indicated that the miR-23b expression level was higher in endometrial cancer tissues (2.70 44.45$)$ than the miR-203 expression level $(-2.34 \pm 4.08)$ (Figure 1). The endometrial cancer tissues showed the overexpression of miR-23b in 30 (71.4\%) of the 42 endometrial cancer cases, whereas miR-203 was underexpressed in 29 (69.0\%) of the 42 cases. There was a significant association between miR-23b and miR-203 expression in endometrial cancer

Table 1. Relationship between miR-23b and miR-203 in endometrial cancer tissues

\begin{tabular}{lccc}
\hline \multirow{2}{*}{ Expression } & miR-23b level & miR-203 level & \\
\cline { 2 - 3 } & $\mathrm{N}(\%)$ & $\mathrm{N}(\%)$ & \\
\hline Over & $30(71.4)$ & $13(31.0)$ & \\
Under & $12(28.6)$ & $29(69.0)$ & 0.0005 \\
Total & $42(100)$ & $42(100)$ & \\
\hline
\end{tabular}


tissues $(p=0.0005)$ (Table 1$)$.

\section{DISCUSSION}

miRNAs, which are 21 25 nucleotide functional RNA molecules, represent a class of short noncoding RNAs [3]. They play an important regulatory role in sequence-specific base pairing on the 3'UTRs of mRNAs, thereby inhibiting translation and promoting mRNA degradation [3]. miRNA dysregulation has been reported in many human diseases, including cancer $[5,13]$. Among studies that have reported miRNA dysregulation, several studies have shown the upregulation or downregulation of miRNAs in endometrial tissue samples [9]. However, the underlying mechanisms leading to endometrial cancer development are not yet fully understood.

Specific overexpression or underexpression has been correlated with particular tumor types. For example, miRNA overexpression can result in the downregulation of tumor suppressor genes, whereas miRNA underexpression can lead to oncogene upregulation. The expression of miR-23b in cancer is controversial because it has been found to be upregulated and oncogenic in kidney and gastric cancer, where it causes the translational repression of tumor suppressor PTEN genes [14]; however, it has also been found to be downregulated and act as a tumor suppressor gene in prostate and bladder cancer, where it directly targets Src kinase and Akt oncogenes [15]. In the present study, the overexpression of miR-23b was detected in $30(71.4 \%)$ of the 42 endometrial cancer tissues studied. miR-203 is a skin-specific miRNA that is specifically expressed in keratinocytes and promotes epidermal differentiation [12]. The etiology of miR-203 expression in cancer has not been elucidated; some studies have shown an increase in colorectal and breast cancer [12,16], while other studies have shown a decrease or no change in colorectal and esophageal cancer $[12,17]$. In the present study, the underexpression of miR-203 was detected in 29 (69.0\%) of the 42 endometrial cancer tissues studied. Many studies have been conducted on miRNA expression in cancer, but miR-23b and miR-203 expression in normal endometria and in endometrial hyperplasia has yet to be reported; thus, further studies on this topic are needed.

The expression of miRNA can be regulated by several mechanisms, including genomic loss, epigenetic modification, and transcriptional regulation [18]. miR-23b and miR-203 have been reported to suppress cancer cell proliferation, invasion, and metastasis [18]. The modulation of miR-23b and miR-203 expression by genetic and epigenetic silencing has been conducted in various tumors [19]. Majid et al. [15] reported that miR-23b is methylation-silenced tumor suppressor in prostate cancer, and its high expression level was found to be associated with higher survival rates in prostate cancer patients [14]. Further, Huang et al. [7] reported that the hypermethylation of miR-203 was found in endometrial cancer cell lines. When these cancer cells were treated with inhibitors of DNA methyltransferases and histone deacetylases, the expression of miR-203 was reactivated [7]. The findings of these studies suggest that miR-203 expression might be subject to epigenetic regulation.

Further studies are needed to define the role of miRNAs and methylation in endometrial tumorigenesis. The importance of studying the role of miRNAs in endometrial tumorigenesis is further highlighted by the many factors known to be involved in its regulation. A complex network of regulatory mechanisms results in the tissue-specific expression of miRNAs in various types of cancer; as such, further studies are needed on this topic. In summary, this study was conducted to analyze miR-23b and miR-203 expression in endometrial cancer tissue samples using qRT-PCR. This study indicated that miR-23b and miR-203 are involved in post-transcriptional regulation and that miR-23b overexpression and miR-203 underexpression may play roles in endometrial carcinogenesis. Further studies are required to define the relationship between the expression of specific miRNAs (e.g., miR-23b and miR-203) and that of tissue-specific proteins. 


\section{요 약}

MicroRNA는 작은 비암호화 RNA로서 유전자 발현을 조절 한다. 다양한 인체 종양에서 특이 miRNA 발현의 변화가 보고되 면서 종양 발생에 중요한 역할을 수행하는 것으로 알려졌다. 최 근에는 자궁내막암종을 포함한 다양한 암종에서 여러 miRNA 의 비정상적인 발현이 보고되었으나, miR-23b와 miR-203 발 현에 대한 연구 결과는 아직 국내에 보고되지 않았다. 따라서 본 연구에서는 자궁내막암종에서 miR-23b와 miR-203의 발현을 비교하고 상호 연관성을 분석하고자 하였다. 인체 자궁내막암 종으로 진단된 파라핀 블록 42건을 대상으로 quantitative real-time PCR을 이용하여 miRNA 발현 수치를 분석하였다. miR-23b 발현 수치는 $2.70 \pm 4.45$ 로 miR-203의 발현 수치 $-2.34 \pm 4.08$ 보다 높게 나타났다. 또한 miR-23b는 총 42건 중 30건(71.4\%)에서 양의 발현이 나타났고, miR-203은 총 42 건 중 29건(69.0\%)에서 음의 발현이 나타났으며, 이는 통계학 적으로 유의한 차이를 나타냈다 $(p=0.0005)$. 따라서 본 연구에 서는 miR-23b와 miR-203 발현은 자궁내막암종 발생에 연관 이 있을 것으로 추정되며, 향후 miR-23b 와 miR-203 발현과 조직특이 단백 발현과의 상호 연관성에 대한 연구가 더 필요할 것으로 사료된다.

\section{Acknowledgements: None}

Funding: This work was supported by RESEARCH FUND offered from Catholic University of Pusan.

Conflict of interest: None

\section{REFERENCES}

1. Banno K, Kisu I, Yanokura M, Masuda K, Kobayashi Y, Ueki A, et al. Endometrial cancer and hypermethylation: regulation of DNA and microRNA by epigenetics. Biochem Res Int. 2012; 738274. doi: 10.1155/2012/738274.

2. Poy MN, Eliasson L, Krutzfeldt J, Kuwajima S, Ma X, Macdonald $\mathrm{PE}$, et al. A pancreatic islet-specific microRNA regulates insulin secretion. Nature. 2004;432:226-230.

3. Qin X, Yan L, Zhao X, Li C, Fu Y. MicroRNA-21 overexpression contributes to cell proliferation by targeting PTEN in endometrioid endometrial cancer. Oncol Lett. 2012;4(6):1290-1296.

4. Gilabert-Estelles J, Braza-Boils A, Ramon LA, Zorio E, Medina P, Espana F, et al. Role of microRNAs in gynecological pathology. Curr Med Chem. 2012;19(15):2406-2413.

5. Choi WS, Kwon KC. Expression of micro RNA in paraffin embedded tissue of multiple myeloma. Korean J Clin Lab Sci.
2015;47(4):292-297.

6. Yanokura M, Banno K, Kobayashi Y, Kisu I, Ueki A, Ono A, et al. MicroRNA and endometrial cancer: roles of small RNAs in human tumors and clinical applications (Review). Oncol Lett. 2010;1(6):935-940.

7. Huang YW, Kuo CT, Chen JH, Goodfellow PJ, Huang TH, Rader JS, et al. Hypermethylation of miR-203 in endometrial carcinomas. Gynecol Oncol. 2014;133(2):340-345.

8. Castilla MÁ, Moreno-Bueno G, Romero-Pérez L, Van De Vijver K, Biscuola M, López-García MÁ, et al. Micro-RNA signature of the epithelial-mesenchymal transition in endometrial carcinosarcoma. J Pathol. 2011;223(1):72-80.

9. Lee H, Choi HJ, Kang CS, Lee HJ, Lee WS, Park CS. Expression of miRNAs and PTEN in endometrial specimens ranging from histologically normal to hyperplasia and endometrial adenocarcinoma. Mod Pathol. 2012;25(11):1508-1515.

10. Ma G, Dai W, Sang A, Yang X, Gao C. Upregulation of microRNA-23a/b promotes tumor progression and confers poor prognosis in patients with gastric cancer. Int J Clin Exp Pathol. 2014;7(12):8833-8840.

11. Majid S, Dar AA, Saini S, Deng G, Chang I, Greene K, et al. MicroRNA-23b functions as a tumor suppressor by regulating Zeb1 in bladder cancer. PLoS One. 2013;8:e67686. doi: 10.1371/journal.pone.0067686.

12. Li J, Chen Y, Zhao J, Kong F, Zhang Y. miR-203 reverses chemoresistance in p53-mutated colon cancer cells through downregulation of Akt2 expression. Cancer Lett. 2011;304(1): 52-59.

13. Han C, Yu Z, Duan Z, Kan Q. Role of microRNA-1 in human cancer and its therapeutic potentials. Biomed Res Int. 2014; 428371. doi: $10.1155 / 2014 / 428371$.

14. Zaman MS, Thamminana S, Shahryari V, Chiyomaru T, Deng G, Saini $S$, et al. Inhibition of PTEN gene expression by oncogenic miR-23b-3p in renal cancer. PLoS One. 2012;7(11):e50203. doi: 10.1371/journal.pone.0050203

15. Majid S, Dar AA, Saini S, Arora S, Shahryari V, Zaman MS, et al. miR-23b represses proto-oncogene Src kinase and functions as methylation-silenced tumor suppressor with diagnostic and prognostic significance in prostate cancer. Cancer Res. 2012; 72(24):6435-6446.

16. Furuta M, Kozaki KI, Tanaka S, Arii S, Imoto I, Inazawa J. MiR-124 and miR-203 are epigenetically silenced tumor-suppressive microRNAs in hepatocellular carcinoma. Carcinogenesis. 2010;31(5):766-776.

17. Chiang Y, Song Y, Wang Z, Chen Y, Yue Z, Xu H, et al. Aberrant expression of miR-203 and its clinical significance in gastric and colorectal cancers. J Gastrointest Surg. 2011;15(1):63-70.

18. Li XJ, Ren ZJ, Tang JH. MicroRNA-34a: a potential therapeutic target in human cancer. Cell Death Dis. 2014;5:e1327. doi: 10.1038/cddis.2014.270.

19. Bueno MJ, Perez de Castro I, Gomez de Cedron M, Santos J, Calin GA, Cigudosa JC, et al. Genetic and epigenetic silencing of microRNA-203 enhances ABL1 and BCR-ABL1 oncogene expression. Cancer Cell. 2008;13(6):496-506. 